Vol. 16, $n^{\circ} 1$ | 2012

Varia

\title{
The Great 'Reading' Experiment : an Examination of the Role of Education in the Nineteenth-century Gaol
}

Rosalind Crone

\section{(2) OpenEdition Journals}

Electronic version

URL: https://journals.openedition.org/chs/1322

DOI: $10.4000 /$ chs. 1322

ISSN: 1663-4837

Publisher

Librairie Droz

\section{Printed version}

Date of publication: 1 May 2012

Number of pages: $47-74$

ISBN: 978-2-600-01594-3

ISSN: 1422-0857

Electronic reference

Rosalind Crone, "The Great 'Reading' Experiment : an Examination of the Role of Education in the Nineteenth-century Gaol", Crime, Histoire \& Sociétés / Crime, History \& Societies [Online], Vol. 16, $n^{\circ} 1$ | 2012, Online since 01 May 2015, connection on 23 March 2022. URL: http://journals.openedition.org/ chs/1322 ; DOI: https://doi.org/10.4000/chs.1322 


\title{
The Great 'Reading' Experiment: an Examination of the Role of Education in the Nineteenth-century Gaol'
}

\author{
Rosalind Crone ${ }^{2}$
}

\begin{abstract}
Cet article examine l'apparition, durant la première moitié du XIX é siècle, de programmes destinés à l'instruction des détenus, et particulièrement sur le programme mis en auvre à la prison de Reading dans les années 18401850. Durant cette période, un aumônier des prisons enthousiaste, John Field, parvint à convaincre les autorités locales de reconstruire la prison du comté, d'imposer le système de l'isolement permanent des détenus, d'abolir le travail forcé et de consacrer le temps des détenus à l'étude intensive des Écritures et de textes similaires. La prison de Reading est un exemple de l'adaptation des méthodes et techniques éducatives à un environnement et à un public spécifiques, la prison et les condamnés. Replacés dans son contexte pénal et éducatif, cet exemple montre également que si les programmes d'instruction pénitentiaire ont fréquemment (et à juste titre) été associés à la réforme spirituelle des détenus, une base de soutien plus élargie garantissait la survivance d'une instruction élémentaire pour les prisonniers adultes illettrés, alors même que les autorités centrales faisaient pression en faveur de l'adoption du travail forcé, d'une alimentation et d'un couchage à la dure dans les prisons locales.
\end{abstract}

This article explores the emergence of schemes for educating prisoners during the first half of the nineteenth century, focusing on the programme of instruction at Reading Gaol during the 1840s and 1850s. During this period, the enthusiastic prison chaplain, John Field, convinced the local authorities to rebuild the county gaol, impose the separate system of prison discipline, abolish hard labour, and devote prisoners' time to the intensive study of the Scriptures and other related texts. Reading Gaol provides an insight into how educational methods and techniques were modified to suit a particular environment - the prison-and a particular student body-convicted criminals. When viewed in its educational and penal context, Reading Gaol also shows that although schemes for educating prisoners have often (and rightly) been associated with spiritual reformism, wider bases of support ensured the

1 I would like to thank Gill Sutherland, David Vincent, Peter Mandler, Peter King, Simon Devereaux, Bob Owens, Shaf Towheed, Katie Halsey, members of the ICCCR at the Open University and the anonymous referees at Crime, History and Societies for their help and encouragement in the preparation of this article.

2 Rosalind Crone is lecturer in history at the Open University (UK). She has published widely on popular culture, crime and literacy in the nineteenth century, is author of Violent Victorians: Popular Entertainment in Nineteenth-Century London (Manchester University Press, 2012), and co-editor (with Shafquat Towheed) of The History of Reading, Volume 3: Methods, Strategies, Tactics (Palgrave, 2011). She is currently writing a book on educating criminals in nineteenth-century England. 
survival of at least elementary instruction for illiterate adult prisoners even when central authorities pressed for the adoption of hard labour, hard board and hard fare in local gaols.

Tn 1885, Edmund Du Cane, chairman of the new Prison Commission established to ensure the conformity of all prisons to a harsh and deterrent penal regime, reflected on the great variety in prison discipline that had existed only forty years previously. He selected Reading Gaol as a prime example:

[here] hard, heavy labour was absolutely forbidden in order that whole attention might be devoted to literature - the establishment was a criminal university, and acquired the name of the "read-read-Reading Gaol". As a final climax of burlesque absurdity the Bible was made the principal lesson book (...) and a reformatory influence was supposed to be achieved by requiring the criminals to commit large portions of the Testament to memory. This result was (...) so effectively achieved that a felon was said to have been so distressed that the end of his sentence interrupted his studies when he had only 'got as far as the Ephesians' that he came back (under the sentence of sheep-stealing) to learn the rest of the Testament ${ }^{3}$.

Reading Gaol has been regarded as similarly quirky by criminal justice historians, though not necessarily out of the ordinary. Scholars writing in the wake of both Whiggish $^{4}$ and Foucauldian 5 accounts of the rise of the prison have shown that penal reform in the period 1770-1850 was uneven and highly variable: these studies have exposed the gap between rhetoric and practice, the disparity between the intentions of penal reformers and the results their designs produced, and the tension that existed between the desire to reform offenders and the need to punish them ${ }^{6}$. Reading Gaol has been cited as one of a range of examples between c.1830 and c.1850 of local prisons which, with enthusiastic prison chaplains and willing local authorities, adopted the separate system of prison discipline and pursued religiously-based reformative techniques, but which subsequently abandoned these when cries about perceived prison comforts and crime waves forced a new emphasis on hard labour, hard board, and hard fare 7 . Reading Gaol was more extreme than, say, the Preston House of Correction, and its uniqueness has led historians to dismiss its significance.

However Reading Gaol deserves further examination for what it can tell us about the role of education in the nineteenth-century gaol. Little attention has been paid to the educational programmes constructed for prisoners over the course of the nineteenth century by either criminal justice historians or education historians. For the former, prison education sits uncomfortably with the dominant trends in prison discipline that shape our understanding of the penal experience, namely, the attempts to reform criminal offenders during the first half of the century, accompanied by a discourse of criminality which stressed the environmental roots of crime, and the emphasis on punishment and deterrence during the second half of the century, as

Du Cane (1885, p. 57).

Webb, Webb (1922); Radzinowicz, Hood (1990).

Foucault (1977); Ignatieff (1978); Evans (1982).

6 DeLacy (1986, 1981); Zedner (1991), and more recently, Brown (2003, especially pp. 55-82); Ireland (2007).

7 Forsythe (1987); McConville (1995, 1981); Wiener (1990); Henriques (1972). 
criminality was increasingly seen as hereditary and thus the criminal irredeemable. Hence the provision of education is often seen as bound up with spiritual reformism. Yet the schoolmaster had a growing rather than retreating presence in the prison as the century progressed; compulsory education was utilised as a punishment for criminal or potentially criminal juveniles after 1856 , and even the sceptical Du Cane, quoted above, did not advocate the exclusion of education, even for adult prisoners, but carefully wove it into the prison regime he imposed on convict and later local prisons $^{8}$. Education historians and more recently historians of reading have shown a preference for highlighting diversity in the acquirement of the literary skills and the degree of choice in the use of those skills in an effort to debunk earlier studies based on notions of social control. Those who have made brief forays into the area of prison reading have emphasised the agency of the prisoners while neglecting to make proper reference to the context of this reading, namely the coercive penal regime and the disciplinary functions of instruction offered to prisoners?

The value of Reading Gaol (and other experiments in educating prisoners), becomes apparent when the gaol is placed within both the educational context and the penal context. The latter has been well established by criminal justice historians. The importance of the involvement of evangelicals in the penal reform movements of the period 1770 to 1850 , and the complexity of their intentions, has been laid out by historians such as Henriques, Forsythe and McGowen ${ }^{10}$. In particular, during the 'penal crisis' of the 1830s, when rising crime rates in towns and countryside sparked debate about the progress of reform, the evangelical mission acquired a fresh dimension, the promotion of the separate system of discipline, a penal regime which, through the separate confinement of prisoners in individual cells, promised the painful solitude and reflection necessary to encourage the reformation of the offender. Although, through the appointment of William Crawford and Whitworth Russell to lead the new prison inspectorate in 1835, the separate system became the favoured mode of prison discipline in Whitehall, the central government lacked the power to enforce reform at the local level. However, in several instances the campaigns of dedicated prison chaplains met with some success. Thus solitary confinement and intensive religious instruction are indicative of the implementation of the separate system at Reading Gaol.

Yet there is also an educational context for the Reading experiment which needs to be understood. The drive to educate the masses from the turn of the nineteenth century, evident in the flowering of a range of schools for the children of the poor, was largely supported by a series of investigations highlighting the links between low educational attainment and crime ${ }^{11}$. Thus not only was the need for elementary

\footnotetext{
8 See description of that system in Du Cane (1885, pp. 79-85).

9 For example, Bell (2004); Hartley (2011), but less so Rogers (2009), who seeks to place convict James Brown's use of literary skills within the context of the disciplinary relationship between him and the prison visitor, Sarah Martin.

10 Forsythe (1987); Henriques (1972); McGowen (1986); and for earlier period, Thorness (2009).

11 For example, see Bowles (1819); Best (1827); Wilderspin (1823), Select Committee on the Education of the Lower Orders of the Metropolis, PP (1816), IV, p. 232, Select Committee on the Education of the People of England and Wales, and Grants in Aid, PP (1834), IX, p. 49, Select Committee on the Education of People of England and Wales, and Grants in Aid, PP (1835), VII, pp. $31 \&$ 131, Select Committee on the Education of the Poorer Classes in England and Wales, $P P$ (1837-1838), VII, pp. 41-42, 96 \& 108, Select Committee on Manchester and Salford Education, PP
} 
instruction for the masses recognised, but so too was the need for provision of education for those who had already embarked on criminal careers. The government signalled its commitment to the education of criminals in the official instructions issued to surgeon-superintendents of convict ships in 1815 (to establish schools for juveniles) and 1832 (to instruct all convicts) and in the Gaols Act of $1823^{12}$. Although this commitment was mostly rhetoric as the government lacked power to enforce these provisions, especially in local gaols, the presence of these clauses encouraged experimentation.

It is also true that this legislation combined elementary education with religious instruction. However, during the first half of the century, many contemporaries and educational providers saw religious instruction as education, and the teaching of the skills of reading and writing as mere tools to enhance that instruction. By the 1840 s, the overwhelmingly religious content of popular education had started to come under attack, sparked by Frederick Liardet's study on the state of the peasantry in Kent in the wake of the Battle of Bossenden Wood in 1838, which found that the almost exclusive presence and use of the Bible in homes and schools had made the labouring poor vulnerable to the machinations of a man claiming to be the Messiah $^{13}$. Bossenden Wood has been viewed as an important turning point towards the secularisation of at least state-sponsored education, largely accomplished in the Revised Code of $1862^{14}$. Debates that raged in the two decades between these events were largely supported by evidence on literacy collected at local gaols and national penitentiaries. Studies produced by the new statistical societies, for example, emphasised that, as criminals demonstrated a wide range of skills, the relationship between education and crime was complex. Hence, the failure of education to stop crime was not a failure of education per se, but rather a failure of existing modes of education. In particular, these studies reinforced the importance of the moral content of popular education ${ }^{15}$.

It was in this climate that the Reading experiment was launched, and as such the gaol provides a useful example of how forms of learning and educational methods were adapted to a particular environment - the prison - for a distinctive student body - criminals. Amidst calls for a change in the type of education offered to the masses, Field attempted to reassert the value of religiously-based elementary instruction, especially for criminals. Reading came to bear the hallmarks of a Foucauldian institution, and ultimately the prison environment restricted what could be achieved. But the 'failure' of Reading and other religiously-based experiments in prisons did not deal a death blow to efforts to educate criminals. Instead, the consistent focus on the criminal population in discussions about popular education ensured that even

(1852), XI, pp. 85-86. The schools established, and their raison d'être, are described by education historians: Vincent (1989, pp. 73-75); Sutherland (1990, pp. 126-131); Lacqueur (1976); McCann, Young (1982); Steward, McCann (1967); Schupf (1972).

12 Select Committee on the State of Gaols and the best method of providing for the Reformation of Offenders, PP (1819), VII, Appendix s: Instructions to Surgeons and Superintendents, p. 558, Instructions to Surgeons and Masters of Convict Vessels during Voyages to Foreign Settlements, $P P$ (1834), XLVII, Gaol Act 1823 (4 Geo. IV c.64).

13 Liardet (1839, especially pp. 128-129); Vincent (1983, pp. 209-213); Reay (1991).

14 Vincent (1989, pp. 73-92); Sutherland (1990, pp. 141-142).

15 Cullen (1975, p. 73); Beirne (1993, pp. 128-133); Porter (1837); Rawson (1841, p. 334); Fletcher $(1847,1849)$. 
though instruction in the elements was largely de-coupled from religious instruction, the moral purpose of mass-education, as an antidote to the immoral lifestyle of the poor and as part of the defence against crime, was never seriously challenged.

\section{REGIME}

Historians have most often highlighted limits of reform in local gaols in the period 1770-1850, drawing attention to the reluctance of budget-conscious and conservative-minded local magistrates to bend to the will of central policymakers ${ }^{16}$. The Berkshire magistrates, in contrast, appear to have been exceptionally progressive as, throughout this period, Reading Gaol matched most trends in penal policy and the bench showed willingness to engage with the centre. After the publication of damning reports on the state of England's gaols by John Howard, in 1786 the original county gaol at Reading was rebuilt. The local authorities also boasted that they had been the first county to adopt the treadmill, that new instrument of punishment recommended by the Society for the Improvement of Prison Discipline in 1822. While it was true that during the $1820 \mathrm{~s}$ and 1830 s rising crime rates, or rather the growing use of imprisonment as a punishment for crime, swelled the prison population at Reading causing overcrowding, the quarterly reports from the Visiting Justices and annual reports from the prison chaplain, Robert Appleton, made frequent references to the acceptable state of the buildings and the orderly behaviour of the inmates ${ }^{17}$.

The new prison inspectors, William Crawford and Whitworth Russell, did not agree with this assessment. In their first report on Reading Gaol in 1837 they described at length the unacceptable system of discipline in operation. Although Crawford and Russell acknowledged that the silent system had been adopted for convicted male prisoners, the inspectors found that because these men were not under constant supervision, they were more or less able to freely associate. They also demonstrated a lack of respect towards prison staff, including the prison chaplain. Furthermore, evidence collected by the inspectors showed that no prisoner was released from the gaol as a reformed character. Instead, most were "more decidedly corrupt and hardened on their discharge". Partly to blame was the lack of any formal instruction. Although the chaplain distributed religious reading matter to prisoners who requested it and were considered to be "deserving", the inspectors asserted that the prisoners "frequently destroy their books, and their Tracts always"18.

Just as we might be wary of accepting the positive comments made in the Visiting Justices' reports on the state of their gaol, so too should we approach the conclusions made by the prison inspectors with some scepticism. Crawford and Russell compiled their reports with an agenda in mind, to promote the adoption of the separate system throughout England and Wales. As Forsythe has pointed out, the process of prison inspection allowed for the accumulation and thus centralisation of knowledge, an effective weapon as inspectors positioned themselves as experts against local

$\overline{16}$ Delacy (1981, pp. 183-184); Brown (2003, pp. 62-64).

17 For example, Berkshire Record Office (hereafter BRO), Q/ SO 17: Visiting Justices' Reports, 2 January 1838 ; 3 April 1838; 3 July 1838; 16 October 1838; 1 January 1839; 9 April 1839; 2 July $1839 ; 15$ October 1839. See also Southerton (1993, pp. 11-19).

18 Inspectors of Prisons, Home District, Second Report, PP (1837), XXXII, pp. 246-259. 
officials who they depicted as archaic and parochial ${ }^{19}$. In the case of Reading Gaol, the magistrates appear to have taken this report seriously. A few years earlier they had established a gaol committee to enquire into the possibility of adopting the separate system of discipline, but the visit of the inspectors had prompted new consideration of the issue ${ }^{20}$. At the same time, they turned their attention to the role of the prison chaplain.

Appleton was not a particularly active chaplain. His performance was adequate, but he did not seem to demonstrate a great commitment to the job. In August 1839, Appleton accepted the position of Headmaster at Reading School, which meant that he was frequently absent from his duties at the prison. Within a few months, the magistrates had decided to force his resignation ${ }^{21}$. His replacement was John Field, a young man in his mid to late twenties, who was a native of Berkshire but had been working as a clergyman in a parish of Worcester. There he had also occasionally officiated at the county gaol, which was similarly organised according to the silent system $^{22}$. By the time of Field's arrival, the tone of the internal reports on Reading Gaol had changed. The Visiting Justices had begun to criticise the construction of the gaol, which allowed prisoners to escape on a regular basis, and to lament the poor discipline, which had transformed the gaol into a nursery of crime, evident in the high number of recidivist offenders in the county ${ }^{23}$.

Hence the conditions were ripe for an ambitious young chaplain, such as Field, to make his mark. His first annual report presented at the Michaelmas Quarter Sessions in 1840 was in effect a dossier of the abuses within the prison. Field drew attention to the "poor" state of the chapel and the "disgusting" practice of forcing ten or more prisoners into one small cell. These conditions, he argued, prevented any hope of improvement in the morals of the inmates. Free association meant that if any prisoner expressed regret, penitence or desires of amendment, he became "the object of ridicule and amidst the wickedness in which he is compelled to remain; it can be no matter of surprise that these better feelings prove transient" 24 .

Over the next twelve months, Field's complaints, supported by the Visiting Justices, in particular William Merry, and the prison governor, Lieutenant Edward Hackett, convinced the county magistrates that some sort of action was essential. At the Michaelmas Quarter Sessions in 1841, a committee was appointed to consider the list of recommendations compiled by Field, namely, the separate confinement of prisoners, the appointment of a schoolmaster, the enlargement and redesign of the chapel, the reduction of the time spent in hard labour and the abolition of the treadmill ${ }^{25}$. The committee reached the conclusion that the current gaol was inadequate and suggested that a new gaol might be constructed for about $£ 15,000$, along the lines of the model penitentiary at Pentonville which, by giving each inmate

\footnotetext{
19 Forsythe (1991). See also Hennock (1982); Brown (2003, pp. 62-64).

20 BRO, Q/ SO 17: Chaplain's Report, 15 October 1839.

$21 \quad$ BRO Q/ SO 17: Visiting Justices' Reports, 15 October 1839; 31 December 1839; Inspectors of Prisons, Home District, Fifth Report, PP (1840), XXV, p. 26.

22 Inspectors of Prisons, Southern and Western District, First Report, $P P$ (1836), XXXV, pp. 79-83.

23 BRO Q/ SO 17: Visiting Justices' Reports, 31 December 1839; 7 April 1840; 30 June 1840; 20 October 1840.

24 BRO Q/ SO 17: Chaplain's Report, 20 October 1840.

25 BRO Q/ SO 17: Chaplain's Report, 18 October 1841.
} 
his or her own cell, would enable the penal administrators in Berkshire to impose the separate system of prison discipline. The magistrates sanctioned the plan and entered into consultation with Sir Joshua Jebb, commissioner of Pentonville, who, on behalf of the Home Office, advised on and approved the design and layout put forward by the architects, Gilbert Scott and William Moffat ${ }^{26}$. The result was the construction of an imposing, but highly decorative neo-gothic building, containing 230 individual cells, and, on a slightly elevated aspect, overlooking the town of Reading. In other words, Reading Gaol resembled a castle (see fig. 1).

It was, however, over budget, the total cost to the county being $£ 46,000$, around three times the original estimate. The decorative features added to the exterior of the building were in part responsible for the rising costs: $£ 3,500$ was spent on pure embellishment where only $£ 350$ had been put aside for this ${ }^{27}$. Such expenditure encouraged some to mock the pretensions of the gaol, and later others highlighted the inappropriateness of accommodating the lowest in society in that which resembled the most important institutions in the land ${ }^{28}$. But in the 1840s at least, these voices were in the minority and misunderstood the importance of the symbolism of prison design. Grandeur in the fortification of prisons, such castellation and the use of features such as a portcullis, not only established a link with prisons of the past, but also emphasised the barrier between the outside and inside worlds. As John Pratt has written, the gothic imagery established the prison as a 'house of secrets', the message conveyed to the general public being that inside the walls was a place of pain, suffering and no escape ${ }^{29}$.

A large component of that pain, Pratt continued, was inflicted on inmates in prisons such as Pentonville through hard labour, especially as the time devoted to solitary confinement rapidly decreased. This labour was deliberately made useless in order to enhance the convicts' sense of awe of the punishment and also to deter would be offenders. Hence, Pratt sees Pentonville and other model prisons as far from Foucault's disciplinary machine: Foucault made much of the efforts to transform the soul, whereas hard labour in the Victorian prison was essentially used to teach prisoners a lesson ${ }^{30}$. Similarly, Henriques has suggested that the pursuit of the twin aims of reformation and deterrence through the separate system limited the extent to which either could produce any notable results ${ }^{31}$. Yet this was not the case at Reading Gaol. Field convinced the county magistrates to do away with hard labour altogether arguing that it was not an effective punishment or deterrent. Instead, machines like the treadmill hardened the male prisoners, making them sullen and irritable and increasing the likelihood of their future recommittal. Moreover, Field complained, it was an uneven punishment, as the degree of labour performed by the prisoners differed according to their weight and stature, rather than by the level of

26 BRO Q/ SO 18: Gaol Committee Report, 3 Jan 1842; BRO, Q/ AG/ 1/3: Schedules of contract for works for the New Gaol, Reading, 1842.

27 BRO, Q/ SO 19: Gaol Committee Report, 16 Oct 1843; BRO, Q/ AG/ 1/ 2: Agreement for securing additional loans for completion of the gaol; BRO, D/ EX 343/ 4: Correspondence with Crown Insurance Company on extension of mortgage; Inspectors of Prisons, Home District, Tenth Report, PP (1845), XXIII, p. 41.

28 For example, the MP Charles Pearson: Pearson (1857).

29 Pratt (1993). See also Evans (1982, pp. 377-383); Tomlinson (1978).

30 Pratt (1993).

31 Henriques (1972, pp. 92-93). 
their guilt. It was also futile: cunning prisoners always discovered ways to avoid the punishment ${ }^{32}$.

The abolition of the treadmill and other forms of hard labour at Reading Gaol did not mean that prisoners escaped punishment for their crimes. Punishment, Field argued, was a vital step in the path towards reformation, but it should complement, rather than distract from or frustrate that goal. Thus, at Reading Gaol, prisoners would be punished by their confinement in separate cells. The benefits of this were two-fold. First, separate confinement would act as a deterrent to those on the outside. Field and Merry both claimed that there was no more terrible prospect for an uneducated and depraved man than imprisonment in an individual cell ${ }^{33}$. By the 1850s, Field even claimed that separate confinement had deterred vagrants from the county and had been responsible for lowering crime rates in Reading town ${ }^{34}$. Second, separate confinement as a punishment was proportionate both to the offence committed and the character of the prisoner. "Whilst the less vicious ere long find relief", Field declared, "the more dissolute and depraved not only feel their punishment to be far more severe at first, but give evident proof that its severity continues so long as their evil inclinations are cherished" ${ }^{35}$.

It was mostly for its ability to inflict pain that the separate system of punishment enjoyed great support from a large number of penal officials and administrators during the nineteenth century. However, concerns about its ability to drive men insane meant that in convict prisons at least, where those sentenced to transportation or penal servitude were likely to stay for extended periods, time spent in solitude was limited to the first eighteen months (quickly reduced to nine) of confinement. For prison chaplains such as Field, the type of punishment provided by separate confinement was intended to soften the prisoner in preparation to receive the word of God. Locked in his cell with no labour or other diversion, the prisoner would be forced into an intense reflection upon his crimes and former depravity, in time becoming remorseful ${ }^{36}$. Only this type of intense suffering would allow the criminal to reject his past life and embrace a new Christian future. While in such agony, the prison chaplain would visit the prisoner's cell in order to introduce him to the word of God. Historians have already shed light on the nature of the conversations between prisoners and chaplains, from the gentle admonitions and kindness of some (eg. John Clay) to the sermonising of others (e.g. Joseph Kingsmill). They have also made brief reference to the specific techniques adopted, from the distribution of Bibles to the encouragement of the rote learning of the Scriptures ${ }^{37}$. The impression conveyed by these studies is of something that was almost ad hoc and even casual, yet we know that the prison was an institution obsessively focused on routine. In

32 For example, BRO Q/SO 19: Visiting Justices' Report, 16 October 1843; BRO Q/SO 22: Special Report of the Visiting Justices, 1 July 1850; BRO Q/SO 17: Chaplain's Report, 18 October 1841, Field (1848, I, p. 161, 1853, p. 149), Select Committee on the State of Prison Discipline, PP (1863), IX, p. 237 (Hereafter, Carnarvon Committee).

33 Carnarvon Committee, p. 241 ; Field (1848, I, p. 347).

34 Field (1853, p. 143).

35 BRO Q/ SO 20: Chaplain's Report, 13 October 1845.

36 Field (1848, I, pp. 128-129 \& 166), Select Committee on Prison Discipline, PP (1850), XVII, p. 242. (Hereafter, SC (1850)).

37 Forsythe (1987, pp. 44-67); Henriques (1972). 


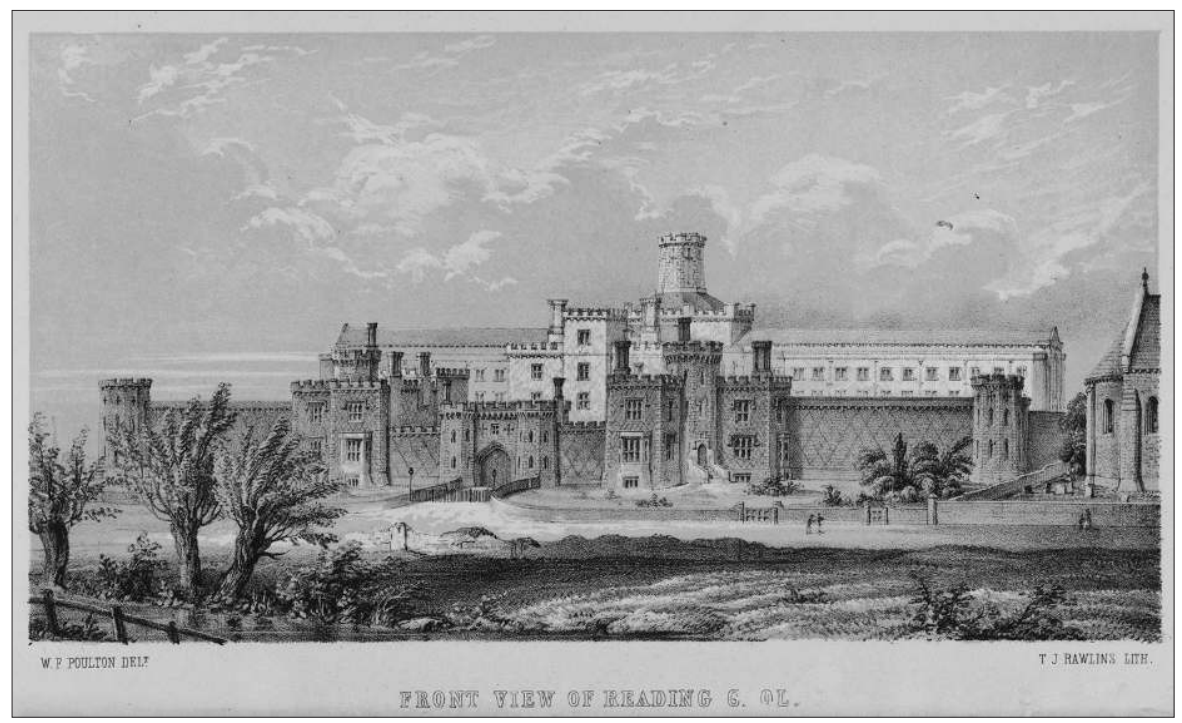

From John Field, Prison Discipline, $2^{\text {nd }}$ edn (London, 1848), vol. 1 frontispiece.

other words, we still have little sense of how religious instruction, or education more generally, operated in practice. Reading Gaol provides at least one clear example.

Convicted male inmates (adults and juveniles) arriving at the new country gaol in Reading from late 1844 were subjected to an entirely new regime. They first faced an inquisition from the chaplain to enable the compilation of sets of data, for example, on their age, previous commitments, level of literacy, level of religious knowledge, and previous schooling ${ }^{38}$. Literacy tests have posed problems for historians. Unfortunately, precise details of how these men and women were tested do not survive. Although local penal officials were instructed to collect this information, no Home Office directive on the criteria to be applied was issued ${ }^{39}$. At some institutions, prisoners responded to a series of questions, while at others they were asked to prove their ability. Given his interest in the accuracy of the results, it seems likely that Field chose the latter method, and probably followed a similar course of action to that of convict-ship surgeon-superintendent Colin Arrott Browning, who placed a book in the convict's hands and asked him to read aloud from it, and requested an example of writing, if the convict claimed he could write ${ }^{40}$. From this first test, prisoners were grouped in the following classes: neither skill; read only; read and write imperfectly; read and write well; and superior education.

After one year of collecting the literacy data, Field concluded that there was no link between illiteracy or poor literacy and crime in Berkshire. While he was disappointed with their poor performance, he argued that the men's literacy was representative of the level of literacy found among the labouring classes in the

\footnotetext{
38 The gaol also held a number of pre-trial prisoners, but these men and women were not subjected to Field's regime before conviction.

39 Gatrell, Hadden (1972, pp. 379-380).

40 Browning (1847, p. 315).
} 
county $^{41}$. Field's conclusions were well grounded. Although on average over the period in which Field collected this data (1845-1857), male prisoners at Reading Gaol (39 per cent literate) lagged about 30 points behind the national rate of literacy (69 per cent) and about 22 points behind the county rate (61 per cent), if we take into account both their social class and age we should expect some substantial gaps in the comparison ${ }^{42}$. Furthermore, we can compare the male prisoners with the data collected by David Vincent from parish registers on levels of literacy within various occupational groups. If we take Vincent's fifth group, unskilled labourers, the prisoners at Reading Gaol more or less match their achievements, Vincent's labourers achieving 31.6 per cent in the period 1839-1854, compared with 38.8 per cent for the prisoners in the period $1845-1854^{43}$.

From 1848 onwards, Field added data on the prisoners' previous schooling. Unfortunately it is limited in scope. Field restricted his inquiry to ascertaining the number of men who had attended school for two years or more. It is also unclear whether his definition of a "school" referred only to the government-sponsored British and Foreign Schools and National Schools, or whether he also included, for example, the Sunday Schools. Across the period 1848-1857 around 45 per cent of the male prisoners attended school for two years or more, a figure that further convinced Field that the problem lay in the type of instruction they had received. As he wrote, "Children - or still childish men - have learnt to read and write, but they have not learnt to think about or to understand anything which they have been taught" 44 .

Hence Field's intensive focus on the prisoners' religious knowledge. The results of his inquiries are presented in table one. Each year, Field found that between 90 and 95 per cent of male prisoners were either ignorant of the Saviour's name and could not repeat the Lord's Prayer, or could repeat the Lord's Prayer but were imperfectly acquainted with simple religious truths, a proportion of prisoners which outstripped the number unable to read or write. There was a level of subjectivity in this assessment, but given the categories set, it does not seem as if Field placed the bar at a particularly high level. So, while attendance of the lower classes at school was an issue that needed to be addressed, much more urgent were deficiencies in the education of those who did attend school. As Field wrote in his annual report in 1849 , "although the lack of secular knowledge may account for much vice, the cause of offences is chiefly the ignorance of criminals on religious subjects" ${ }^{\prime 4}$.

Other prison chaplains agreed with this diagnosis. Together they formed an expert and vocal opposition to calls for the diversification of the content of popular education. H.S. Joseph, chaplain at Chester Castle Gaol, summed up their position in his statement "unless the foundation of education be on religious principle, then better to give them no education at all" ${ }^{46}$. Many drew attention to the improper use of

\footnotetext{
41 BRO Q/SO 20: Chaplain's Report, 13 Oct 1845.

42 Sources for data: BRO Q/SO 20, 21, 22, 23, 24, 25: Chaplain's Reports, 1845-1857, Annual Reports of the Registrar-General of Births, Deaths and Marriages in England, PP (1846-1859).

43 Vincent (1989, pp. 30 \& 97). For a further assessment of literacy data from prisons, see Crone (2010).

44 Field (1848, II, p. 143).

45 Field (1849, p. 10). See also BRO Q/SO 20: Chaplain's Report, 13 Oct 1845, Select Committee on the Execution of the Criminal Law, PP (1847), VII, p. 159. (Hereafter, SC (1847))

46 Joseph (1853, p. 2).
} 


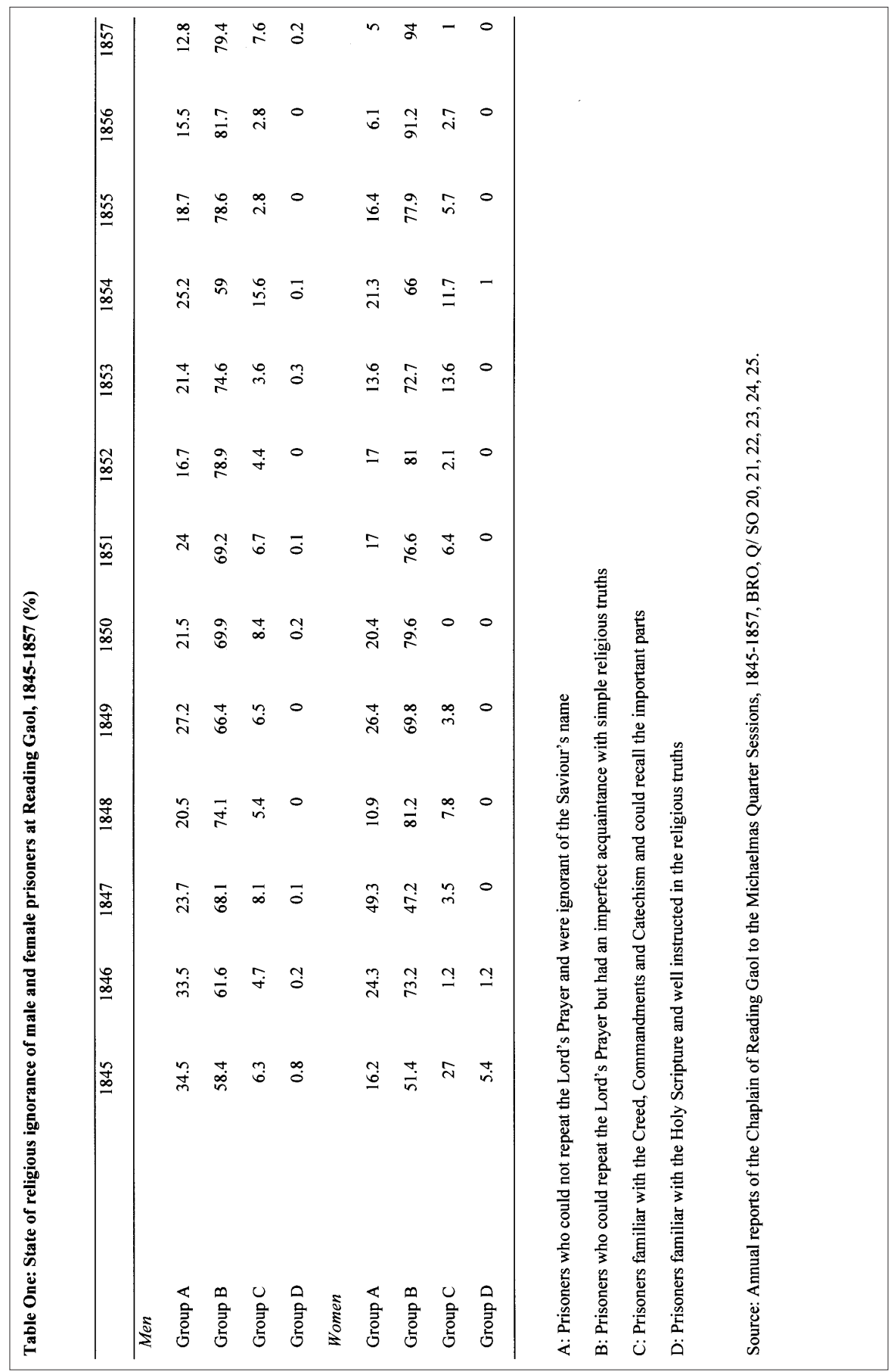


the skills of literacy by those in the lower classes who had learned them, in particular highlighting the detrimental impact of cheap literature by linking publications aimed at the semi- and newly-literate to perceived rising crime rates ${ }^{47}$ John Clay, chaplain at Preston Gaol, conducted a survey of the reading habits of juvenile prisoners to show how the reading of pernicious texts, notably William Harrison Ainsworth's Jack Sheppard, could encourage young, impressionable males into a life of crime ${ }^{48}$.

For Field, the prison environment offered the ideal opportunity both to appropriately educate those who had been neglected and to re-educate those who had forgotten what they had learnt or had used their skills in an inappropriate manner. Thus, education inside the walls of the prison, much more than outside of the prison, had to focus on the disciplining of the mind. Moreover, the skills imparted to criminals in the process of this education had to be controlled. Ideally, prisoners would only acquire those skills necessary for the disciplinary process, namely reading and perhaps writing. Field feared that instruction in arithmetic, for example, "might prove injurious, both to the culprit himself and to society (...) He would become more wise to do evil" ${ }^{4}$. However, Field was also at pains to stress that the programme of instruction he offered within the gaol was not compulsory: to force the convicted to read the Bible would be to encourage an aversion to learning and potentially to do more harm than good ${ }^{50}$. Yet that was not how many of his contemporaries viewed his experiment ${ }^{51}$. Perhaps they were right, for it seems that the prisoners had little choice.

After his initial interview with the chaplain, the prisoner was dispatched to his solitary cell and locked up without anything to do. As William Merry explained to the Select Committee in 1847, in this situation the men soon begged for something to do to relieve their mental suffering. Thus the prisoner "is asked if he would like something to read; if he says yes, he is given a Bible; if he says he cannot read, he is sent a schoolmaster to help him and within about six weeks to three months he acquires enough fluency to read by himself' 52 . Thereafter nearly every hour of every day was devoted to the intensive study of the contents of that book, as revealed by the prison timetable.

Rising at 6am, inmates had three hours to clean their cells and eat their breakfast, leaving time also for reading the Biblical passages which they had been assigned and preparing lessons on these readings for the schoolmasters. Between 9:15 and 10:00, prisoners attended divine service. Rigorous attention during the service was necessary, as Field would visit their cells later in the day to interrogate them on the subjects touched upon in the sermon and Scripture readings. At 10:00, an hour was set aside to allow prisoners, dressed in anonymous garb, time out of their cells for exercise. The hour between 11:00 and 12:00 was, on alternate days, devoted to classes from the chaplain which focused on issues of morality, with reference to the Bible, or in catechetical instruction; on other days the prisoners were employed in

\footnotetext{
47 For example, Wontner (1833); Kingsmill (1854, pp. 39-42).

48 Select Committee on Criminal and Destitute Juveniles, PP (1852), VII, appendix no. 3. (Hereafter, $\mathrm{SC}(1852))$

49 Field (1848, I, p. 158 (quote), 308).

50 Select Committee on Criminal and Destitute Children, PP (1852-53), XXIII, pp. 212-213.

51 For example, John Clay at Preston, SC (1852), p. 189.

52 SC (1847), p. 479.
} 
cleaning the gaol or in reading in their cells. Dinner was served between 12:00 and 13:00, after which, for the next two hours, the prisoner would read or, if permitted, relax with some other employment in his cell. If he could not read, he would receive instruction in this skill from the schoolmaster. Twice a week, during this time, he could also expect a visit from the chaplain. Exercise was again permitted between 15:00 and 16:00. And in the two hours before supper, the schoolmasters would instruct the remainder of the prisoners and hear their lessons repeated. Finally, the time between supper and lights-out was devoted exclusively to "mental and moral improvement" (i.e. more Bible reading) ${ }^{53}$.

Two schoolmasters were employed to assist Field. Notably, despite the tools they were given to work with (religious literature), and the content of the education offered, their primary task could be described as secular. Aided by lesson books published by the Society for the Promotion of Christian Knowledge (SPCK), the schoolmasters helped those who were entirely illiterate to acquire first the skill of reading and subsequently the skill of writing ${ }^{54}$. They would also visit those who already had enough ability to begin solitary study to listen their recitations of memorised Biblical verses. But the schoolmasters were directed by Field only to correct the diction of the prisoners and where necessary provide basic definitions for words. As Field was concerned that some inmates would be tempted to "put puzzling questions to the schoolmaster", any discussion of the subject matter was to be left to the chaplain ${ }^{55}$.

Field also determined the stages through which the prisoner was to progress with his learning. Given the diverse range of skills prisoners exhibited there was some variation in the pace by which prisoners would advance, but at least from the surviving evidence there seems to have been little attempt to tailor the official programme to individual circumstances, for example, by setting Biblical verses deemed relevant to an individual's circumstances. The course of instruction at Reading was designed to impart the basic religious truths, and, in as short a time as possible, provide the prisoner with an understanding of his sin and God's forgiveness as well as methods for applying religious knowledge to everyday life.

After learning to recite the Lord's Prayer, memorising the catechism and studying "The Divines of our Blessed Lord" (an SPCK tract), prisoners would embark upon a specific course of Bible-reading, beginning with the Gospels (starting with St John), followed by the other books of the New Testament, and then, time permitting, the books of the Old Testament. Field, like other penal officials, knew that distributing Bibles to inmates without providing direction for its consumption could be dangerous. George Holford, one of the founders of Millbank Penitentiary, expressed concern that without guidance, the prisoner would view the Bible "merely as a storybook, to choose out such parts as shall afford him entertainment, and even to dwell upon those chapters or expressions which, in his ignorance, and with his bad dispositions, he may misinterpret into something like a sanction or precedent for his own acts of

Field (1848, I, pp. 156-158).

54 See orders of books in the Visiting Justices' Order Book, Reading Gaol, 1841-1863, The National Archives (hereafter TNA), PCOM 2/ 394.

55 SC (1850), p. 262, Inspectors of Prisons, Home District, Fourteenth Report, PP (1850), XXVIII, p. 57. 
vice or folly"56. Although much of the Bible reading at Reading was undertaken by prisoners in seclusion, the men were kept from straying to other parts of the book through the task of memorising set verses. With periods of punishment staggered throughout the prison, Field and the schoolmasters produced weekly reports to keep track of the readings each prisoner had been allocated as well as to supervise their rate of progress through the Bible (a sample is produced in table two).

Although commonly used in church-run elementary schools during the first few decades of the nineteenth-century, rote learning of this kind had come under sustained attack and in many instances curtailed by the 1840s. However, within the prison environment, the memorisation of the Scriptures had benefits. At least one historian has suggested that it had practical advantages: the cells that prisoners were confined in were small and relatively ill-ventilated placing restrictions on the type of labour that could be carried out - "reading the Scriptures took up no space and little air" 57 . It also could consume vast amounts of time that might otherwise be spent in lonely idleness. Finally, memorisation was cost efficient, an activity that did not require constant supervision. Beside these immediate "practical advantages", memorising the Scriptures had specific disciplinary uses. The Visiting Justices saw in rote learning a "standard punishment of the school authorities" adapted for use as a penal punishment, believing that was both more irksome and more productive than the physical labour of the $\mathrm{crank}^{58}$. After all, memorisation provided finelytuned training in concentration. However, John Field preferred to draw attention to its soul-saving qualities. He argued that seclusion combined with a programme of memorisation encouraged a more intimate relationship between the prisoner and his Bible: "Debarred from evil communications the prisoner becomes conversant with his Bible ... whilst it prevents despondency it proves attractive. The truth being thus received in the love thereof regulates the life, and the sinner becomes wise unto salvation" 59 .

Field was also anxious that the prisoners should demonstrate an understanding of the passages they read and that they should be able to apply the lessons learnt to their lives upon release from the gaol ${ }^{60}$. Therefore, those who had progressed far enough with their reading were subjected to open-book examinations. Since the opening of church-run elementary schools in the 1810 s, textbooks had been developed which asked children to apply the lessons of the Scriptures to the stories with which they were presented. For example, in some, pages were divided into two columns, the story placed on the right with a series of questions matched to the text on the left. As J.M. Goldstrom has written, "there was an earnest desire on the part of the compilers that the Bible should be seen to have a relevance to everyday life" ${ }^{\text {" }}$.

Field adapted this pedagogical method for use inside the prison. The exam questions were related to what Field believed were the causes of crime. Underlying all of these was the lack of religious education, which meant that men were not in control of their passions, fell into lives of vagrancy, were seduced by the tempting

\footnotetext{
56 Holford (1828, p. 160).

57 Tomlinson (1978, p. 68).

58 BRO Q/SO 22: Special Report of the Visiting Justices, 1 July 1850.

59 Field (1848, I, p. 343).

60 SC (1850, p. 239).

61 Goldstrom (1977, pp. 95-99).
} 


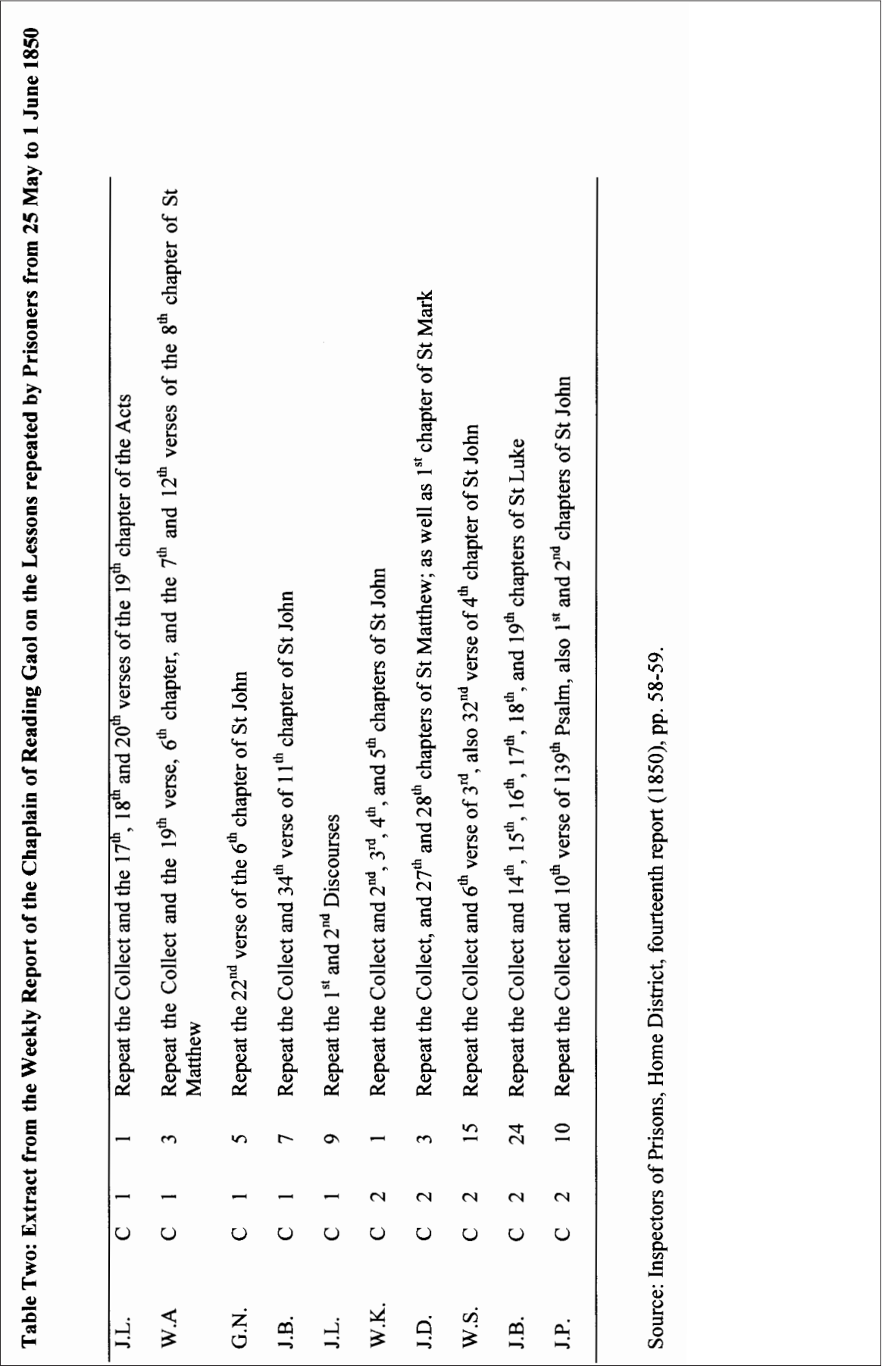


pleasures of the beer-house, penny gaffs and other immoral pursuits, and were encouraged into regular Sabbath-breaking62. Thus prisoners were asked: "Why should I obey the Eighth Commandment?"63; "Give reasons why we should not frequent the public-house"; "In what sense is God our Father"; "Why should I obey the Fourth Commandment?" ${ }^{4}$, and "Give reasons why we should always speak the truth". The men were required to answer with specific points supported by references or verses from the Bible ${ }^{65}$. For example, in providing reasons to avoid the publichouse, one prisoner, I.N., who had memorised the Gospels and several chapters of the Old Testament during his three-month confinement, wrote:

1. Because we can get no good there. Luke xi. 4.

2. Because we should not go into bad company. Psalm i. 1. 1 Thess. v. 22. Proverbs i. 10.

3. Because we should not set a bad example. Luke xvi. 28. James iv. 17. Psalm cxl. 11.

4. Because we can employ our time better. Ephes. v. 15,16. Titus ii. 11,12. 2 John xi. 11. Psalm xc. 12.

5. Because we shall have to render a strict account of our lives at the day of judgement. Luke xvi. 2. Proverbs xxix. 1. Eccles. iii. 15, 17.

6. Because we should not encourage drunkenness, folly and vice. 1 Cor. vii. 31. Psalm ix. 17. Proverbs iv. 14, $15^{66}$.

Field also intended that the prisoners would feed these lessons back into the depraved society from which they came. One inmate, imprisoned for six months for threats to murder, was set this exam question: "Give advice to a drunkard, supported by texts of Scripture" ${ }^{67}$. Field was overjoyed to read the letter of another, J.I., sentenced to eighteenth months' imprisonment for a felony, which he addressed to his sister in February 1848:

The particular [sin] is drinking, which brought me very low; and if you read the following verses, you will see that I have proved them. Prov. xx. 1; Prov. xxiii. 21 \& 32; Haggai. i. 6; Prov. i. 31; Prov. xiii. 15-21; Prov. xi. 21; Isaiah xlviii. 22; Jer. xxii. 21. And now my dear sister, seeing I have proved this, I do heartily pray that you will correct your son betimes, and he will give you comfort and joy (...) if you read the following Scriptures, you will see that your thoughts cannot stand. Ezekiel xviii ; Colos. iii. 25; Mark xvi. 16; Luke xii. 3 \& 5; Psalm ix. 17; Psalm xi. 6. This shows us plainly that all who don't repent must suffer the vengeance of eternal fire. Read St John's gospel, and there you will see that Jesus died for sinners ${ }^{68}$.

Prisoners were further aided in their studies by a number of small tracks printed by the SPCK, most of which had been written by Field for the purpose of educating criminals. For example: the convicted arriving at the prison could expect to receive

\footnotetext{
62 Field (1849, pp. 10-15).

63 For example, 'Thou shalt not steal', Exodus 21: 15.

64 For example, 'Remember the sabbath day, to keep it holy', Exodus $21: 8-11$.

65 SC (1850, pp. 241-242).

66 Field (1848, II, pp. 121-130).

67 Ibid., p. 129.

68 Field (1848, I, pp. 297-299).
} 
"Friendly Advice to a Prisoner", those about to be discharged would be given "A Chaplain's Word at Parting", and many during their confinement would probably encounter, "Some Account of Thomas Jennings", a moral tale about a prisoner recently hanged for murder at Reading Gaol ${ }^{69}$. Furthermore, in 1847 the use of Reading Gaol as a holding pen for those convicts sentenced to transportation but who could not be accommodated in the national penitentiaries introduced Field to marginal Bibles. The pages of these Bibles were divided into three sections: the main body of Biblical text was framed by a left-hand column directing the reader to parallel references, and a bottom row giving brief explanations of the verses ${ }^{70}$. Seeing the great potential of these textbooks, Field began to replace the plain Bibles with the marginal Bibles. While the notes provided constant instruction, the parallel references allowed the prisoner to navigate his way around the whole Bible in a relatively short space of time, directing him to the immediately relevant lessons and providing some understanding of how the seemingly discordant parts linked together.

Finally, advancement in learning, as demonstrated through the amount of text memorised, success in examinations and a display of pleasure in the task, was rewarded. Some prisoners were given supervised access to the prison library where they were exposed to other religious texts, as well as some more general reading on history and geography ${ }^{71}$. For the majority, their efforts were rewarded with physical labour, or "relaxation", as the authorities at Reading called it. The amount and type of labour was restricted to that which would help to stimulate the mind but not exhaust the men. Oakum was placed in the prisoners' cells, and so in William Merry's oftquoted phrase, "when they are tired of reading, they pick a little oakum" 72 . Otherwise, prisoners would be sent outside, in their peaked caps, to work at the prison water pumps, to help whitewash the walls, or to work in the gardens, all in silence ${ }^{73}$. The small number of inmates engaged in industrial labour were the convicts sentenced to transportation. For the county prisoners, far from teaching the men new skills or habits of industry, Field believed industrial labour would encourage feelings of selfishness and distract from moral reformation, a position which is unsurprising, given the type and scale of criticisms that had been made by many penal reformers towards experiments at prisons such as Preston and Newgate ${ }^{74}$. It was with pride that Field and other prison officials at Reading reported that labour was never forced on

69 Large quantities of both tracks were regularly ordered: TNA PCOM 2/ 394. See also Field's comments about the deficiency of such literature: BRO Q/ SO 2: Chaplain's Report, 16 October 1848, and his system on distribution described in Inspectors of Prisons, Fourteenth Report, p. 56.

70 I am not certain of exactly which edition of marginal Bible Field decided to distribute to the prisoners. I have based this assessment on the editions of the Authorised Version with marginal notes published by the Religious Tract Society in 1838 and 1855 .

71 Inspectors of Prisons, Tenth Report, p. 66: gives a list of the contents of the library at Reading Gaol which did include some secular but improving texts, many of which were likely purchased before Field arrived at the Gaol. However, in December 1855, Field did make an order for more secular as well as religious texts, including travel narratives, a History of England, Industry of Nations, and Natural History of Man. See TNA PRO PCOM 2/ 394.

72 SC (1847), p. 479.

73 Field (1848, I, pp. 154-155).

74 Field (1853, pp. 150-151). 
prisoners, but that all inmates, with very few exceptions, happily completed every task asked of them, providing further proof of their reformation ${ }^{75}$.

Before we turn to consider the implications of Field's regime, we must acknowledge that at least one important group has been left out of this analysis: female prisoners (adults and juveniles). Relatively small numbers of women were sentenced to periods of imprisonment at Reading - on average, there were only ever about twenty women confined in the gaol at any one time ${ }^{76}$. Field did collect data on the characteristics of these women. His statistics showed that even if the women tended to be less literate than the men (able to read and write), in every year a higher proportion of women possessed at least the skill of reading. Furthermore, a larger number of the women had been to school for two years or more. This evidence does pose a challenge to the conclusions of some contemporaries and historians that illiteracy was a characteristic of the female offender ${ }^{77}$. For Field, this evidence perhaps proved the contemporary attitude that criminal women were even more depraved and transgressive than criminal men, and so hopes of reformation were much more limited ${ }^{78}$. After all, if we add Field's early data on religious knowledge, proportionately more women than men were able at least to repeat the Lord's Prayer ${ }^{79}$. For the first few years of the new gaol, women were excluded from Field's programme of instruction. In 1847, however, Field turned his attention to their plight. He expressed concern that the whole of their time was consumed in doing the "washing for the establishment", an arduous task, probably given to the females in order to train their domestic skills, but which had not produced good effects as evident in the high number of recommittals. Field was most likely also concerned about the sudden peak in the proportion of females demonstrating complete religious ignorance: in 1847, around half of the women committed could not repeat the Lord's Prayer, compared with about one quarter of the male committals (see table one). In following year, Field convinced the Berkshire magistrates that a portion of the prison laundry should be reallocated to the male prisoners so that the women might have some time for religious instruction ${ }^{80}$. But this provision was limited, and the persistent absence of the female prisoners from Field's proofs of reformation, annual reports and published discussions demonstrates the extent of their exclusion.

\section{CRITIQUE}

It is clear from the above description that the new county gaol at Reading bore the hallmarks of a Foucauldian disciplinary regime. In contrast to the findings of Margaret Delacy, at least in the first few years of the regime, "the dreams of

75 Carnarvon Committee (1863, p. 244); SC (1850, p. 262).

76 This low number is unsurprising. A number of historians have drawn attention to the vanishing female in the nineteenth-century criminal justice system, though disagreement persists on whether this was a reflection of reality (fewer women committing crime) or attributable to administrative changes: Feely, Little (1991); King (2006, ch. 6); Zedner (1991).

77 For example, Rawson (1841, p. 343); Mayhew, Binny (1862, p. 182); Zedner (1991, pp. 142-143).

78 Zedner (1991 pp. 18-23, 27-33 \& 40-46); Damousi (1997, p. 22).

79 For example, collected in 1841 and again in 1845. BRO Q/ SO 17: Chaplain's Report, 18 October 1841 ; BRO Q/ SO 20: Chaplain's Report, 13 October 1845.

80 Field (1848, I, p. 164). 
visionary fanatical prison inspectors" and chaplains did seem to match up with the realities of the local gaol ${ }^{81}$. Field not only compiled data about the individuals under his care, but used that knowledge to exert power over their bodies. The men were subjected to a regime that was designed to correct their abnormalities. Hence the education offered to inmates was corrective, not enlightened; through memorisation, recitation and examinations, the men were being disciplined in the accumulation and application of a particular type of knowledge. At Reading Gaol we can see precisely how disciplinary methods from the monastery and schoolroom were adapted for the purposes of reforming criminals. Furthermore, Field was hopeful that the influence of the education within the prison would extend into the working-class community, and encouraged his pupils to pass their knowledge on to family and friends. He also expressed a desire that the county workhouses, dens of vice and feeding institutions for the gaol, would adopt a similar regime and likewise become valuable "Houses of Correction" $" 82$.

At least in its first years, this experiment in prison discipline also showed some signs of success. Prison inspectors Crawford and Russell voiced their approval in their inspection report for 1845. "The records of this prison", they wrote, "undeniably prove that Separation, as a system of discipline, is highly conducive to the acquirement of habits of industry", and that the committed study of the Scriptures "must, doubtless, have their influence in the formation of good moral principles" $" 83$. Field began to set himself up as an expert on penal regimes. He embarked upon a fruitful publishing career and attended national and international conferences to promote the Reading experiment ${ }^{84}$. For example, Field was a member of several committees responsible for the influential lobbying of the government on penal policy ${ }^{85}$. Field announced to the Berkshire magistrates on his return from a conference in Brussels that both Reading Gaol and Pentonville had been referred to by experts from sixteen different countries as "models of prison construction which must be imitated" and as "affording patterns of discipline which must be universally copied"86.

But it seems as if, despite these efforts and at times high acclaim, no one in Britain or in the Western world did attempt to copy the Reading experiment. Moreover, the regime established at Reading lasted barely a decade. This stands in direct contrast to the arguments of Michel Foucault who suggested that the disciplinary society created in the period 1770-1850 persisted deep into the twentieth century. As Forsythe writes, "Foucault did not realise that after 1860 the interventive and moral reformatory project he had unearthed suffered massive and almost terminal damage" ${ }^{87}$. Forsythe and other historians have pointed to a series of key shifts or external pressures which forced the reformatory penal regime into decline and prompted the rise of the harsh, mid-Victorian prison in which inmates were subjected to punishing degrees of hard

\footnotetext{
81 Delacy paraphrased by Forsythe (1995, p. 266).

82 Field (1848, II, p. 146).

83 Inspectors of Prisons, Tenth Report (p. 47).

84 Most of Field's publications have already been referred to in the above notes. For others, see bibliography, as well as three papers published as part of the Transactions of the National Association for the Promotion of Social Science (1857, 1864, 1871).

85 For the importance of such committees, especially in the post-Reform Act state, see Goldman (2002).

86 BRO Q/ SO 21 : Chaplain's Report, 18 October 1847.

87 Forsythe (1995, p. 266).
} 
labour. The end of transportation to Australia combined with a perceived violent crime wave for which ticket-of-leave men were held largely responsible not only contributed to fears about the reintegration of hardened offenders into the community, but encouraged the rise of a new discourse of criminality, which explained the actions of the criminal as hereditary and therefore marked the individual as irredeemable. The public, not to mention a new generation of penal officials, articulated their acceptance of this new ideology through the invocation of the test of "less eligibility" and demands for the greater punishment of prison inmates ${ }^{88}$.

However, the records of Reading Gaol question the extent to which such external pressures can be held accountable for the demise of Field's regime. It is true that a substantial number of prominent officials and commentators believed that the lack of hard labour at Reading failed to deter criminals and the education offered even held out inducements. Misinformation abounded in the statements made by educated men for whom reading and learning were pleasurable activities. For example, the Rev. Henry Phibbs Fry, after making a tour of English prisons, wrote of the Reading inmates :

... their confinement can scarcely be termed a punishment; and it is in fact a retreat from the troubles and wants of ordinary life to repose, abundance, instruction, study, amusement (...) An inspector is compelled to believe not only that thousands would gladly resign liberty for the remainder even of their lives to be received into such an asylum, but that many would purchase permission were it permitted to do $\mathrm{so}^{89}$.

These external comments were not replicated in the discussions of the local officials about penal discipline. As we might expect, given that Reading Gaol was a local prison, little reference was made to the abolition of transportation or the violent crime wave. The repeated requests from the Home Office after the deaths of Crawford and Russell for Reading Gaol to impose some sort of hard labour on prisoners were ignored by the magistrates ${ }^{90}$. Thus we need to look elsewhere for evidence of the emergence of a new discourse of criminality which might have had an impact on the regime at Reading. The intense debates that erupted over the proofs of reformation from Reading Gaol should be a key place to find this. In order to prove the success of his regime, Field collected statements from inmates and copies of letters sent to homes in which the prisoners described the effects of his system of instruction. Most statements resemble conversion narratives, the moment of enlightenment or turning point being the men's close engagement with the text of the Bible. As one convicted criminal declared to Field:

What a blessing it is that I was put into a cell with nothing but my Bible, and could not get away from it! For the first three or four weeks I used to take it up and throw it down again, and curse it; but I could not help taking it up; and what a blessing it has turned out! I seem to have been brought here that I might read

88 For example: Davis (1980); Bartrip (1981); Forsythe (1987, p. 143-149); McConville (1995, especially p. 16).

89 Fry (1850, p. 26).

90 That is, although the requests from the central government were acknowledged, and even a committee established to consider hard labour, any proposals to reinstate it were made entirely on their own terms. BRO Q/SO 23: Visiting Justices' Report, 7 April 1851, and Report of the Committee appointed to consider the best means of providing hard labour at Reading Gaol. 
the Bible, and now I believe it. I shall forever bless God that I was brought to this prison $^{91}$.

Field was not the only chaplain to collect statements and several historians have made remarks on the meaning of these emotional pleas. Some have found it difficult to disagree with many contemporaries, that such displays were essentially hypocritical, an attempt by prisoners to curry favour with the chaplains in hope of benefits or even long-term rewards including early release ${ }^{92}$. In a slightly different vein, Henriques has suggested that this "religious emotionalism" could be explained as a result of the strains of prison life, the need to have a voice amidst the silent regime $^{93}$. Forsythe goes even further, arguing that although prisoners were forced to frame their self-disclosures within specific religious narratives, for example, a stereotyped vice to crime progression, this language should not lead us to distrust all prisoner confessions ${ }^{94}$.

It is not the intention of this paper to evaluate prisoners' confessions, but rather to show how Field sought to spearhead the contemporary debate about reformation by providing different types of evidence from Reading Gaol. Thus, he presented the Quarter Sessions and the Select Committee on Prison Discipline in 1850 with copies of examinations completed by those who had been confined for six months. As it turned out, those scripts which he had placed in the public domain had been prepared by inmates with the aid of the recently acquired marginal Bibles. On learning this, the Visiting Justices expressed their outrage, claiming that the use of marginal Bibles had invalidated the results. To make matters worse, Field's intransigence on the issue forced the Visiting Justices to involve the Bishop of the diocese and Home Office officials in the dispute before they were able to reach a fragile ceasefire ${ }^{95}$.

The dispute justified the rigorous questioning pursued by the Home Office prison inspector on his next visit to the gaol. At the Select Committee in 1850, William J. Williams had already described the system of instruction as a "useless exercise of memory". The interviews he conducted during his visit in 1851 revealed that many prisoners had no understanding of the passages they were asked to memorise and had no desire to become acquainted with their meaning. For instance, inmate 110 told Williams, "I do not understand what I have learnt. I do it as well as I can. I do not recollect all what I have learnt by heart". Prisoner 4429, who had been at Reading Gaol seven times, stated "I have learnt all the Galatians through by heart, and am now upon the Ephesians. I cannot say I understand it. I know the commandments." He repeated his last lesson "perfectly" to Williams when requested, "but was ignorant of the meaning of what he had acquired" 96 . However, despite the public embarrassment and the anger of the Visiting Justices, on the local level there seems to have been little doubt about the positive results of memorisation and examination.

\footnotetext{
$91 \quad$ Field (1848, I, p. 331).

92 For example, Grocott (1980, p. 38-57); Bell (2004).

93 Henriques (1972, p. 82).

94 Forsythe (2001).

95 BRO, Q/SO 23: Visiting Justices' Report, 14 October 1850, \& Memorial of the Chaplain, 14 October 1850 ; BRO Q/ SO 23: Copy of a letter from the Visiting Justices to the Secretary of State, Sir George Grey, 23 November 1850, and TNA PRO, PCOM2/ 394, Visiting Justices' Order Book, 17 August 1850, 24 August 1850 \& 26 October 1850.
}

96 Inspectors of Prisons, Home District, Fifteenth Report, PP (1851), XXVII, pp. 70-72. 
Field also attempted to prove the worth of his experiment through the prison's recommittal rates. Data he collected showed that re-committals had decreased after the opening of the new gaol. However, by 1850 they had again reached previous levels and over the course of the next five years continued to rise ${ }^{97}$. In response to these figures, Field mounted a convincing defence claiming that rates of re-committal demonstrated no significant increase if those prisoners who were unable to benefit from the programme of learning he had developed were excluded from the analysis. These included: re-offenders who had not before been confined at Reading; those who, given their background, would be likely to reoffend even if their reformation had been sincere (mainly juveniles who, on release, were sent back into the care of parents who had long criminal records); and finally, those prisoners who had previously been confined at Reading but for a period of three months of less, a term of imprisonment, Field argued, that was inadequate and did more harm than good ${ }^{98}$.

Even if the method was accepted as sound, in 1849-1850 the assumption that those who had not been returned to Reading Gaol had been reformed was attacked through a private investigation sponsored by the MP Charles Pearson, a fierce and vocal opponent of Reading Gaol in particular, and the separate system in general. Pearson employed private investigator James Acland to scrutinise the claims made by Field and the Berkshire magistrates. Acland's research showed, first, that since the opening of the new gaol both committals and re-committals in Berkshire had increased and second, that no offender who had experienced the regime at Reading Gaol had been seriously reformed. Interviews with local police officers revealed that out of 375 prisoners who had served more than three months at Reading : 108, having borne good character previous to their first offence had returned to honest labour and were no better or no worse; 142 who, before committal, were notorious drunkards, prostitutes or of loose character, had returned to their profligate lifestyles on release; 124 had been recommitted to one of the county gaols; and only 1 could be said to be a reformed character ${ }^{99}$.

Yet still, the county magistrates stood in support of Field and continued to show faith in the system of prison discipline which they had constructed. However, while the regime held up against external pressure, internal strains meant that it soon began to crumble. Ultimately, Reading Gaol demonstrates that Foucault's disciplinary society failed to come about because where disciplinary regimes did emerge these were essentially unsustainable. The first clue lies in Field's number-crunching above, namely, in his insistence on removing prisoners who had spent less than three months confined at Reading from the analysis of the success of the project. Between 1845 and 1853, one third of convicted males at Reading were serving sentences of less than one month, and almost two thirds left the prison before two months had expired ${ }^{100}$. There were limits on what could be achieved in that time frame. Like other prison chaplains, Field regularly bemoaned the imposition of short terms

\footnotetext{
${ }_{97}$ Inspectors of Prisons, Fourteenth Report, p. 61. However, in the late 1850s, it was suggested that there had been a gradual reduction in the number of prisoners across the county between 1847 and 1856, in the order of about 10 per cent. See Inspectors of Prisons, Southern District, Twenty-third Report, $P P$ (1857-1858), XXIX, p. 12.

98 SC (1850), pp. 252-253.

99 Pearson (1857), SC (1850), pp. 646-647.

100 Data derived from the annual judicial statistics, until 1857 attached to the annual reports of the Prison Inspectors, after 1857 as a separate series.
} 
of imprisonment by magistrates, especially for juvenile males ${ }^{101}$. But to make the suggested alterations to sentencing would be to interfere with other fundamental principles upon which the English criminal justice system rested.

It is also clear from looking at the prison records that Field's system could not operate at its full potential given the staff to prisoner ratio. Over the period 1845 to 1857, the prison contained, on average, at any one time, around 115 male inmates. About one third of these men could neither read nor write, and so required the immediate assistance of the schoolmaster in order to have any chance of experiencing the full 'benefits' of Field's regime. The prison timetable above suggests that two schoolmasters were allocated four hours each day to visit the prisoners. If the schoolmasters spent 60 minutes with each illiterate prisoner every week (or roughly ten minutes per day), a time period which does not, at least at first glance, appear to be enough to impart the skill of reading, that would leave only 12 minutes for every other prisoner each week, a portion of whom would be waiting for instruction in writing, and all of whom would need to have their Bible recitations approved. Similarly, we are told that the chaplain visited all prisoners twice a week in the two hour slot before dinner. In practice, each visit, if evenly distributed, would have only lasted around four minutes. Thus it is likely that these prisoners spent long periods of time in idleness, or at least sitting and inactive. Reports from the prison surgeon suggested that some sort of action was necessary ${ }^{102}$.

Therefore, in 1854 penal labour was once again re-introduced at Reading Gaol, in the form of grinding wheat to make bread for the prison. Crucially, the discussions at the Quarter Sessions show that it was not introduced as a concession to the central authorities (who would have preferred useless labour anyway), but to improve the peculiar system of discipline in operation. The additional time allocated for exercise and manual labour was welcomed by Field who had complained about the lethargy of the prisoners caused by the effects of a liberal diet and long hours in bed. Fresh air and exercise would help to reinvigorate the mind ${ }^{103}$. Over the next two years, time spent in labour was gradually increased, again with the support of Field, though also with his caution, that before allowing access to labour inmates should first spend valuable time in seclusion ${ }^{104}$.

We might also wonder whether the introduction of labour was a response to the number of punishments for infractions of discipline within the gaol. As Delacy has stated, records of punishments are ambiguous : a high number of punishments could be indicative of a severe regime in which everyone was disciplined, or an institution where the authorities had lost control. In general, however, Delacy suggested that a lack of whippings (the most severe punishment) combined with a consistent level of minor punishments should signal a gentle maintenance of order ${ }^{105}$. The punishment records at Reading surprisingly show consistency in the transition from the old

101 Especially after the passing of the Juvenile Offenders Act of 1847, extending the reach of summary jurisdiction. For Field's comments, see BRO Q/ SO 23: Chaplain's Report, 13 October 1851 and 18 October 1852.

102 BRO Q/ SO 24: Surgeon's Reports, 1853-1854, Visiting Justices' Reports, 26 June 1854 \& 16 October 1854. Carnarvon Committee (1863, p. 240).

103 BRO Q/SO 24: Chaplain's Report, 16 October 1854; BRO Q/ SO 25 : Chaplain's Report, 15 October 1855.

104 BRO Q/SO 25: Chaplain's Reports, 15 October 1855 \& 19 October 1857.

105 Delacy (1981, pp. 194-198). 
regime to the new in the 1840s. The decline in the number of punishments occurs when labour is re-introduced between 1853 and $1856^{106}$. This evidence might suggest that there was some kind of constant but relatively low-level resistance to Field's programme of instruction. The chaplains who succeeded Field made references to the rough handling of books by some of the prisoners. For instance, in his first report in 1858, Richard Manl wrote that "the want of care in the use of books has caused it to be a prominent item in the lists of punishments for the past year". By 1860, Manl had decided to allocate books only to those prisoners who demonstrated an appreciation for them ${ }^{107}$.

For the four years of his appointment (1858-1861) Manl remained largely committed to the system of prison discipline that Field had established. However, Manl's successor, John Burleigh Colvill, when appointed to the post of prison chaplain in late 1861, immediately set to work disassembling it. Colvill explained to the county magistrates that "if we are to look to reformation of character as well as to punishment of crime, I should think that longer periods of imprisonment with the regular following of trades united to secular and religious instruction in well ventilated cells would accomplish much more than has hitherto effected" 108 . Within the next year, stone breaking had been introduced at the gaol, one of the schoolmasters dismissed, and the time for instruction limited to the evenings ${ }^{109}$. The actions of these individuals highlight the extent to which the regimes pursued in local gaols were dependent upon particular personalities. Field's regime failed to survive because, after 1857 , the two key supporters, the prison governor and the prison chaplain, were no longer present to uphold it.

However, the removal of these men did not mean that the educational project was also entirely set aside. Both instruction in the basic skills and instruction in religious truths remained part of the prison regime at Reading after 1860, as it did in local as well as convict prisons across England and Wales.

How do we explain this continued attachment to educating criminals in the context of the rise of a new discourse on criminality and the greater emphasis placed on the need to punish offenders? As shown above, in the Reading example the persistence of the educational mission can be explained by the way in which the Foucauldian regime imploded. Elements, such as hard labour, introduced with the intention of enhancing the regime contributed to its destabilisation. The result in the 1860s was the emergence of a mix of contradictory components - seclusion, labour, elementary education and religious instruction - none of which could be totally pursued successfully. Yet there is also a clue in the comments of the new chaplain, Colvill, which might help to explain the survival of prison education across the penal system as a whole. In his report of 1862, Colvill described secular and religious instruction as two separate endeavours, in contrast to the firm position of Field and other prison chaplains like him. In the climate of disenchantment with the religious endeavour in prisons (described by historians such as Forsythe and

\footnotetext{
106 Data derived from the annual judicial statistics, until 1857 attached to the annual reports of the Prison Inspectors, after 1857 as a separate series.

107 BRO Q/SO 26: Chaplain's Reports, 18 Oct 1858, 15 Oct. 1860. See also Brown's work on inmate sub-cultures: Brown (2003).

108 BRO Q/SO 27: Chaplain's Report, 13 Oct. 1862.

109 BRO Q/SO 28: Chaplain's Report and Visiting Justices' Report, 17 October 1864.
} 
McConville), the education of prisoners retained a foothold because it could be neatly siphoned off and regarded as a separate programme. This process was assisted by the enlarged commitment of the government to the education of the masses and the inherent secularisation (but not 'de-moralisation') of that education in the 1862 Revised Code. It was also reflected in the 1865 Prison Act, in which elementary instruction was decoupled from the provision of religious instruction, the Visiting Justices becoming responsible for the oversight of the first, and the chaplain afforded a reduced role in managing the second ${ }^{110}$.

Instruction in the 3Rs - reading, writing and arithmetic - was of use in the new penal regimes of the mid-Victorian period because it continued to offer a way of occupying prisoners, from those in separate confinement, to those who, labouring all day, were in need of an evening activity. But also because it continued to provide at least part of the raison d'être for the use of imprisonment as a punishment for crime. Even where public discourse on criminality promoted stereotypes of the irredeemable criminal, prisons could not exist solely as institutions to administer punishment. To earn their keep in terms of contributing to lowering crime rates, at least some lip service to the reformatory ideal was necessary. Educational programmes provided the perfect solution. Data collected at prisons continued to show a link between low educational attainment and crime. It proved to be a useful smokescreen, as this data, combined with new educational schemes for juvenile delinquents, allowed the state to sidestep the confrontation of issues of poverty which in fact underlay both.

\section{Rosalind Crone \\ Department of History \\ Open University \\ Walton Hall \\ UK - Milton Keynes MK7 6AA}

\section{REFERENCES}

Bartrip, P.W.J., Public opinion and law enforcement: The ticket-of-leave scares in midVictorian Britain, in Bailey, V., (Ed.) Policing and punishment in nineteenth-century Britain, London, Croom Helm, 1981, pp. 150-181.

Beirne, P., Inventing Criminology: Essays on the rise of 'homo criminalis', Albany, State University of New York Press, 1993.

Bell, B., Bound for Botany Bay; or, what did the nineteenth-century convict read?, in Meyers, R., Harris, M., Mandelbrote, G. (Eds), Against the Law: Crime, sharp practice and the control of print, London, British Library, 2004, pp. 151-175.

Best, W.D., Letters on the Increase of Crime viewed in connection with the Education of the People, Worcester, 1827.

Bowles, W.L., Thoughts on the increase of crimes, education of the poor, and the National Schools, in a letter to Sir James Mackintosh, $2^{\text {nd }}$ edn., London, 1819.

Brown, A., English Society and the Prison: Time, culture and politics in the development of the modern prison, 1850-1920, Woodbridge, Boydell Press, 2003.

110 Prison Act 1865 (28 \& 29 Vict., c. 126). Also of relevance, the Prison Ministers Act 1863 (26 \& 27 Vict., c.79), allowing for religious pluralism in religious instruction in prisons. 
Browning, C.A., The Convict Ship, and England's Exiles: in two parts, London, Hamilton, Adams, 1847.

Crone, R., Reappraising Victorian literacy through prison records, Journal of Victorian Culture, 2010, 15, pp. 3-37.

Cullen, M.J., The Statistical Movement in Early Victorian Britain: the foundations of empirical social research, Hassocks, Harvester Press, 1975.

Damousi, J., Depraved and Disorderly: Female convicts, sexuality and gender in colonial Australia, Cambridge, Cambridge University Press, 1997.

Davis, J., The London garrotting panic of 1862: a moral panic and the creation of a criminal class in mid-Victorian England, in Gatrell, V.A.C., Lenman, B. and Parker, G. (Eds), Crime and the law: the social history of crime in Western Europe since 1500, London, Europa, 1980, pp. 190-213.

DeLacy, M., Grinding Men Good? Lancashire's prisons at mid century, in Bailey, V. (Ed.), Policing and Punishment in Nineteenth-Century Britain, London, Croom Helm, 1981, pp. 182-216.

DeLacy, M., Prison Reform in Lancashire, 1750-1850: A study in local administration, Manchester, Chetham Society, 1986.

Du Cane, E.F., The Punishment and Prevention of Crime, London, MacMillan \& Co., 1885.

Evans, R., The Fabrication of Virtue: English prison architecture, 1750-1840, Cambridge, Cambridge University Press, 1982.

Feely, M.M., Little, D.H., The vanishing female : the decline of women in the criminal process, 1687-1912, Law and Society Review, 1991, 25, pp. 719-757.

Field, J., Prison Discipline and the Advantages of the Separate System of Imprisonment, $2^{\text {nd }}$ edn, 2 vols., London, Longman, 1848.

Field, J., Crime: its causes and its cure: a report presented to the magistrates of Berkshire at the Michaelmas Quarter Sessions, 1849, London, Longman, 1849.

Field, J., The Life of John Howard; with comments on his character and philanthropic labours, London, Longman, 1850.

Field, J., Hints on imprisonment and penal labour, in Talbot, C.J.C., (Ed.) Meliora; or, Better Times to Come, $2^{\text {nd }}$ Series, London, 1853, pp. 130-155.

Field, J., Observations on the Discipline and Management of Convicts, and on Tickets of Leave, London, Longman, 1855.

Field, J., Remarks on Imprisonment and Penal Labour, London, Longman, 1864.

Fletcher, J., Moral and educational statistics of England and Wales, Journal of the Statistical Society of London, 1847, 10, pp. 193-247.

Fletcher, J., Moral and educational statistics of England and Wales, Journal of the Statistical Society of London, 1849, 12, pp. 151-176.

Forsythe, W.J., The Reform of Prisoners, 1830-1900, New York, St Martin's Press, 1987.

Forsythe, W.J., Centralisation and local autonomy: the experience of English prisons, 18201877, Journal of Historical Sociology, 1991, 4, pp. 317-345.

Forsythe, W.J., The Garland Thesis and the origins of modern English prison discipline: 1835-1939, Howard Journal, 1995, 34, pp. 259-273.

Forsythe, W.J., Suffering, faith and penitence amongst British prisoners, 1835-1860: the application of a theology, Howard Journal, 2001, 40, pp. 14-25.

Foucault, M., Discipline and Punish: The birth of the prison, trans. by Alan Sheridan, London, Allen Lane, 1977.

Fry, H.P., A System of Penal Discipline with a report on the treatment of prisoners in Great Britain and Van Dieman's Land, London, Longman, 1850. 
Gatrell, V.A.C., Hadden, T.B., Criminal statistics and their interpretation, in Wrigley, E.A. (Ed.), Nineteenth-Century Society: Essays in the use of quantitative methods for the study of social data, Cambridge, Cambridge University Press, 1972, pp. 336-396.

Goldman, L., Science, Reform and Politics in Victorian Britain: The Social Science Association, 1857-1886, Cambridge, Cambridge University Press, 2002.

Goldstrom, J.M., The content of education and the socialisation of the working-class child, 1830-1860, in McCann, P. (Ed.), Popular Education and Socialisation in the Nineteenth Century, London, Methuen, 1977, pp. 93-109.

Grocott, A.M., Convicts, Clergymen and Churches: Attitudes of convicts and ex-convicts towards the churches and clergy in New South Wales from 1788-1851, Sydney, Sydney University Press, 1980.

Hartley, J., Reading in gaol, in Palmer, B., Buckland, A. (Eds), A Return to the Common Reader: Print culture and the novel, 1850-1900, Farnham, Ashgate, 2011, pp. 87-102.

Hennock, E.P., Central/local government relations in England: an outline 1800-1950, Urban History Yearbook, 1982, pp. 38-49.

Henriques, U.R.Q., The rise and decline of the separate system of prison discipline, Past \& Present, 1972, 54, pp. 61-93.

Holford, G., Account of the General Penitentiary at Millbank, London, 1828.

Ignatieff, M., A Just Measure of Pain: the penitentiary in the industrial revolution, 17501850, London, MacMillan, 1978.

Ireland, R.W., 'A Want of Order and Good Discipline': Rules, discretion and the Victorian Prison, Cardiff, University of Wales Press, 2007.

Joseph, H.S., Memoirs of Convicted Prisoners, accompanied by remarks on the causes and prevention of crime, London, Wertheim, 1853.

King, P., Crime and the Law in England, 1750-1840: Remaking justice from the margins, Cambridge, Cambridge University Press, 2006.

Kingsmill, J., Chapters on Prisons and Prisoners, $3^{\text {rd }}$ edn., London, 1854.

Lacqueur, T.W., Religion and Respectability: Sunday Schools and working-class culture, 1780-1850, New Haven, Yale University Press, 1976.

Liardet, F., State of the peasantry in the county of Kent, Central Society of Education: Third Publication of 1839, London, 1839, pp. 87-139.

McCann, P., Young, F.A., Samuel Wilderspin and the Infant Schools Movement, London, Croom Helm, 1982.

McConville, S., A History of English Prison Administration, Volume 1: 1750-1877, London, Routledge \& Kegan Paul, 1981.

McConville, S., English Local Prisons, 1860-1900: Next Only to Death, London, Routledge, 1995.

McGowen, R., A powerful sympathy: terror, the prison and humanitarian reform in early nineteenth-century Britain, Journal of British Studies, 1986, 15, pp. 312-334.

Mayhew, H. \& Binny, J., The Criminal Prisons of London and Scenes of London Life, London, Griffin, Bohn \& Co., 1862.

Pearson, C., What is to be done with our criminals? A letter to the Right Honourable Lord Mayor by Charles Pearson - together with Mr Pearson's speech upon the same subject in the House of Commons, May 15, 1849, London, 1857.

Porter, G.R., On the connexion between crime and ignorance as exhibited in the criminal calendars, Transactions of the Statistical Society, 1837, 1, pp. 97-103.

Pratt, J., "This is not a prison": Foucault, the Panopticon and Pentonville, Social and Legal Studies, 1993, 2, pp. 373-395. 
Radzinowicz, L., Hood, R., The Emergence of Penal Policy in Victorian and Edwardian England, Oxford, Oxford University Press, 1990.

Rawson, R.W., An enquiry into the condition of criminal offenders in England and Wales with respect to education, Journal of the Statistical Society of London, 1841, 3, pp. 331-352.

Reay, B., The context and meaning of popular literacy: some evidence from nineteenthcentury rural England, Past \& Present, 1991, 131, pp. 89-129.

Rogers, H., The way to Jerusalem: reading, writing and reform in an early Victorian gaol, Past \& Present, 2009, 205, pp. 71-104.

Schupf, H.W., Education for the neglected: ragged schools in nineteenth-century England, History of Education Quarterly, 1972, 12, pp. 162-183.

Southerton, P. Reading Gaol by Reading Town, Stroud, Alan Sutton, 1993.

Steward, W.A.C. \& McCann, W.P., The Educational Innovators, London, MacMillan, 1967.

Sutherland, G., Education, in Thompson, F.M.L. (Ed.), The Cambridge Social History of Britain, 1750-1950: Volume 3, Cambridge, Cambridge University Press, 1990.

Thorness, L., A Protestant Purgatory: Theological Origins of the Penitentiary Act, 1779, Aldershot, Ashgate, 2009.

Tomlinson, M.H., "Prison Palace": a reappraisal of early Victorian prisons, 1835-1877, Bulletin of the Institute of Historical Research, 1978, 51, pp. 60-71.

Vincent, D., Reading in the working-class home, in Walton, J., Walvin, J. (Eds), Leisure in Britain, 1780-1939, Manchester, Manchester University Press, 1983, pp. 207-226.

Vincent, D., Literacy and Popular Culture: England, 1750-1914, Cambridge, Cambridge University Press, 1989.

Webb, S. and Webb, B., English Prisons under Local Government, London, Longmans, 1922.

Wiener, M.J., Reconstructing the Criminal: Culture, law and policy in England, 1830-1914, Cambridge, Cambridge University Press, 1990.

Wilderspin, S., On the Importance of Educating the Infant Children of the Poor, London, Simpkin \& Marshall, 1823.

Wontner, T., Old Bailey Experience, London, J. Fraser, 1833.

Zedner, L., Women, Crime and Custody in Victorian England, Oxford, Oxford University Press, 1991. 